\title{
Food Aid and Agricultural Production in Bangladesh
}

\author{
Gordon Nelson
}

\section{Four Questions about Food Aid and Agriculture $^{1}$}

Over the past 30 years, Bangladesh has become a chronic food-deficit country which has relied increasingly on food grain imports to sustain its rapidly growing population at minium calorie levels. These averaged four per cent of domestic production in the 1950s, nine per cent in the $1960 \mathrm{~s}$, and 15 per cent in the 1970s. During the 1950s, most food grain imports were purchased commercially by the government, but since 1963 the major portion has been supplied as food aid. Since 1976, food aid has contributed nearly 90 per cent of total food grain imports and has constituted over 10 per cent of total food grain availability.

The extent of Bangladesh's dependence on food aid - it is one of the main recipients in the developing world - gives rise to concern about its efficacy as a resource-transfer. Conventional wisdom maintains that high levels of food-aid imports cause disincentives to local producers through agricultural policy and prices, leading to a decline in investment in and output from domestic agriculture. In the absence of a general equilibrium price and output determination model, this article examines the evidence in Bangladesh of disincentives (and incentives) for the agricultural sector from food aid, focusing on foodgrains which predominate in farming and are most directly affected by food aid. The analysis centres on four questions relating to the structure of incentives facing Bangladeshi farmers. First, have agricultural prices been too low - absolutely and relatively - during the past 25 years of food-aid imports? Second, if output prices had been higher without (or with less) food aid, what would have been the likely output response? Third, is there evidence of complacency among policymakers toward public-sector agricultural investment and development policies because of food aid? Fourth, did food aid provide any incentives to agriculture?

'This article is based on a chapter in a doctoral dissertation at Stanford University entitled The impact of food aid on the Bangladesh economy. The views expressed are solely those of the author.

\section{Were Agricultural Prices too Low?}

Given the high volume of food grain imports to Bangladesh during the past 25 years, there is little doubt that food grain prices have been lower than they would have been without imports. Since the major portion of imports came as food aid, food aid must bear responsibility for part of this price moderation. The question then is whether or not the prevailing food grain prices were a discentive to farmers. To hold scarcity prices in check is quite different from depressing prices that are barely remunerative to start with. Moreover, in land-scarce Bangladesh, where traditional rain fed agriculture had begun to press on natural limits to production by mid-century, the issues of technological change and the opportunity to invest in modern inputs weigh heavily in the discussion.

\section{Inter-sectoral terms of trade}

The domestic terms of trade between the agricultural and non-agricultural sectors are an important determinant of the distribution of income between sectors. As such, they provide a measure of each sector's capacity to save and invest generally, or, more specifically, a measure of the incentives to produce and sell products to the other sector.

The terms of trade for agriculture in India at the time of independence and partition were 40-50 per cent higher than the 25-year average prior to the 1943 wartime Bengal famine [Wall 1978]. While these estimates for the pre-independence period in India are not applicable to Bangladesh, Government of Pakistan [1951] data for the 1947 to 1950 period using the common 1939 baseyear index for India and Pakistan - suggest that the agricultural terms of trade in Bangladesh remained highly favourable, with the GDP, at constant prices, of total agriculture also rising at 2.8 per cent per annum up to FY 54 (financial year: July 1953-June 1954).

Following the end of the Korean war boom, the domestic terms of trade in Bangladesh moved decidedly against the agricultural sector and production declined, reaching an historical low in FY 55.

Bulletin, 1983, vol 14 no 2, Institute of Development Studies, Sussex 


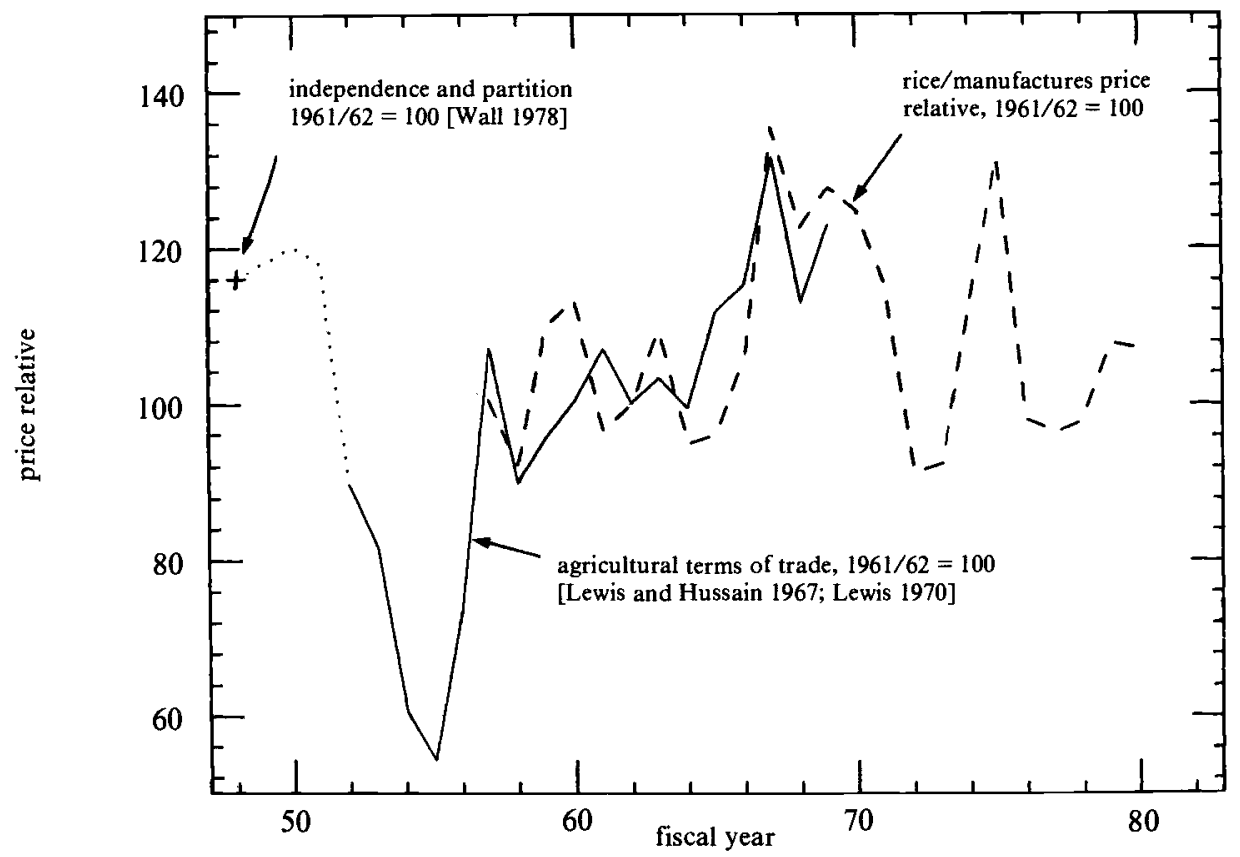

Note: annual data by Lewis and Hussain [1967] and Lewis [1970] adjusted to a 1961/62 baseyear to coincide with Wall's [1978] historical series.

This adverse trend reversed the following year, and agriculture's terms-of-trade position improved steadily throughout the subsequent decade. By FY 69 the terms of trade in favour of agriculture were the highest in history, roughly 40 per cent higher than in FY 52. During this same period, food grain imports had risen from 2 to 10 per cent of net domestic availability. (Net availability $=$ production less 10 per cent allowance for storage losses and retention for seed plus imports plus net carry over of public stocks.)

No detailed analysis of the domestic terms of trade in Bangladesh has been made for the 1970s. The price of rice relative to the price of manufactured goods, which provides an approximation of the agricultural terms of trade, indicates wide fluctuations but no apparent trend. Between FY 71 and FY 80, food aid constituted 10 per cent of net food grain availability; imports constituted 14 per cent. From FY 74, food grain production has grown at an estimated rate of 2.5 per cent per annum.

Given the complex procedures of negotiating and ordering food aid commodities and the time lags involved with shipping and local transport, reliance on food aid probably exacerbated the fluctuations in rice prices and thus the fluctuations in the rice/manu- factures price ratio [Clay 1981]. But the evidence suggests that agricultural producer incentives, as indicated by the domestic terms of trade, were not significantly distorted by food aid or by total food grain imports.

The terms-of-trade indices discussed above relate agricultural prices to the weighted price of all manufactures. The denominator includes manufactured consumption goods as well as agricultural inputs. For traditional agricultural systems that use a low level of purchased inputs, such terms-of-trade measures are appropriate. But as the technology shifts toward modern practices that employ increasing amounts of purchased inputs, a terms-of-trade index that relates agricultural prices to the prices of agricultural inputs becomes more indicative of producer incentives. The rice/fertiliser price ratio indicates a slight upward trend from FY 57 to FY 75, but a 40 per cent decline thereafter, reflecting a reduction in fertiliser subsidies in the late-1970s. Nevertheless, all the fertiliser that has been supplied during the past two decades - including the last five years - has been taken by farmers, and fertiliser is still a relatively small component of total agricultural production costs, some 20 per cent of purchased input costs for HYV (high yielding variety) rice cultivation. 
There has been a gradual upward trend for two decades in the rice/wage price ratio. On average, hired labour continues to be the major purchased input in food grain cultivation, constituting from 40 to 60 per cent of input purchases.

\section{Profitability of food grain cultivation}

Farm management data in Bangladesh are weak, but a review of the calculated average benefit/cost ratios offers some indication of the profitability of food grain cultivation and thus the structure of incentives facing farmers in Bangladesh. An analysis of 40 surveys taken between 1973 and 1980 suggests that, despite considerable variability between seasons and years, the general picture is one of favourable price structures to farmers during the 1970s. The calculated average benefit/cost ratios range from 2.0 to 4.5 for HYVs, excluding imputed family labour costs. Ratios for wheat (which has witnessed the more rapid expansion) are somewhat lower than those for rice, but still profitable. The discrepancy between traditional varieties and HYVs is not surprising considering the large yield difference between varieties.

The generally favourable picture must, however, be qualified by noting the significant differences in benefit/cost ratios for tenant farmers compared to owner-operators. In a system where tenant farmers by tradition provide all the production inputs and then share output 50:50 with the landlords, many benefit/cost ratios for tenants using traditional varieties are less than 1.0, indicating a net loss which translates into growing indebtedness. Ratios for tenants using HYVs are generally higher, ranging from 0.8 to nearly 3.0 , excluding family labour costs.

\section{Incentives for investment in modern agricultural technologies}

Since their introduction in the early-1960s, modern agricultural inputs - fertilisers, pesticides, mechanical irrigation equipment, and HYVs - have been supplied solely by the government through a publicsector agency, the Bangladesh Agricultural Development Corporation (BADC). Most inputs have been imported. The major exceptions are urea fertiliser, which has been produced domestically from natural gas, and second-generation HYV seed, which has been bred and multiplied locally. Compared to existing technological potential (and international standards), the current utilisation of modern inputs in Bangladesh is low.



\footnotetext{
Notes: ${ }^{1}$ food grains $=$ rice and wheat

${ }^{2}$ trend rates $(\mathrm{g})$ are annual compound growth rates estimated by the equation: loge output $=\mathrm{a}+\mathrm{b}$ time.

Entire period $(1948 / 49-1978 / 79, \mathrm{~g}=2.11$ per cent compared with 2.5 per cent population growth.
} 
The government has consistently subsidised input prices for the stated purpose of inducing farmers to adopt and use the new technologies. For example, the subsidy element on fertiliser has ranged from 30 to over 50 per cent; for different types of irrigation equipment subsidies have ranged from 25 per cent (on shallow tubewells) to virtually 100 per cent (on gravity irrigation schemes). Input supplies and subsidies directly affect producer incentives, and they give rise to important questions about public finance and intersectoral resource transfers. A brief review of price policy and use for the major inputs suggests that supply at prevailing subsidised prices rather than low output prices has restricted the growth of input use.

Fertiliser given the high profitability of fertiliser use in rice cultivation (confirmed in farm management and production function studies), the fertiliser market has been characterised as one of persistent excess demand. This is in part due to the large subsidy element in fertiliser prices. Availability, determined by government capacity to acquire commercial or aidfinanced imports, has governed offtake.

Irrigation again input supplies have been limited and official prices to farmers have been heavily subsidised. Virtually all the equipment (pumps and tubewells) supplied was rented (or, in effect, water was sold to farmers) on a seasonal basis and less than 50 per cent of the total capital and operating expenses of the government operation was recouped from farmers. Water from large gravity irrigation schemes has been virtually free to farmers.

Because of inherent 'lumpiness', irrigation equipment is more difficult to re-trade. Consequently, in allocating limited irrigation equipment, price has been less important than political influence with the supply corporation or its agents. Farmers (or farm groups) with political access have obtained pumps at subsidised prices, and then used the pumps often at less than their engineered capacities. With the heavy subsidies there has been little incentive to utilise the pumps to their maximum, and consequently the average capacity utilisation of irrigation equipment in Bangladesh has been low - estimated in recent years at 50 per cent.

In the late 1970s, a change in policy was initiated to transfer gradually small-scale irrigation equipment to the private sector, whereby pumps would be sold to farmers. Because of the policy change, numerous studies (mostly by donor agencies) have been made to estimate the farm-level profitability of pump investments. Calculated internal rates of return, at full economic costs without subsidies, have ranged between 25 and 50 per cent for select types of smallscale irrigation equipment. With subsidies, of course, the incentives have been even higher, indicating generally adequate incentives, since over 20 years all irrigation equipment supplied by the BADC in each season, except one, was taken up by farmers.

The exception was during the FY 77 boro (winter) season when renting out of pump sets - the major source of irrigation - dropped 22 per cent and rice acreage declined 26 per cent from the previous year [Clay 1979, Ahmed 1981]. The short-run structure of incentives had deteriorated for farmers prior to that season. The previous crop year, FY 76, had set a record for rice production. The just-harvested FY 77 main monsoon aman rice crop had nearly equalled the previous year's record. Food imports remained high, partly due to the time lags in supply. Rice prices had dropped some 30 per cent in real terms from the previous year (45 per cent in money terms) during the previous six months. Government also chose this moment to increase rental charges for irrigation equipment.

But the decline in mechanised irrigation and rice production more generally was not solely a question of relative prices. First, 42 per cent of the decline in pump renting occurred in two southern districts, Barisal and Patuakhali, where, according to field reports, farmers' grain stores were literally overflowing from previous good harvests. In these two districts transportation, marketing and government procurement have traditionally been less developed than in northern districts. Similar problems occurred in other districts, in spite of a stepped up domestic procurement programme which netted more than three times the previous record procurement. Second, 45 per cent of the decline in output occurred in one district, Sylhet, where early flooding destroyed much of the crop. Third, fertiliser offtake, in spite of a substantial real price increase, rose at nearly the same rate as total fertiliser offtake increased for the entire year.

High-yielding varieties (HYVs) subsidies on HYV seeds, both imported and locally multiplied, in terms of supply costs have been relatively small. Once released, HYV seeds can be multiplied by farmers themselves and, consequently, an active private market exists for seeds. Regarding the relative profitability of HYVs, the average benefit/cost ratios referred to above suggest that HYV cultivation has been uniformly more profitable than traditional variety cultivation on farmers' fields during the same season.

\section{Domestic and international prices of rice}

For traded commodities, the comparison of domestic prices with world prices is a commonly used indicator of distortions in agricultural output prices. Table 1 suggests that during the past two decades, in spite of 
Comparison of domestic and international prices of rice 1957-79

\begin{tabular}{|c|c|c|c|c|c|c|}
\hline $\begin{array}{c}\text { calendar } \\
\text { year }\end{array}$ & $\begin{array}{c}\text { domestic } \\
\text { wholesale } \\
\text { price } \\
(T k / \text { ton })^{1}\end{array}$ & $\begin{array}{c}\text { official } \\
\text { exchange } \\
\text { rate (OER) } \\
\text { (Tk/dollar) }\end{array}$ & $\begin{array}{c}\text { domestic } \\
\text { wholesale } \\
\text { price at } S E R^{2} \\
\text { (dollar/ton) }\end{array}$ & $\begin{array}{c}\text { inter- } \\
\text { national } \\
\text { price } \\
\text { CIF } \\
\text { (dollar/ton) }\end{array}$ & $\begin{array}{c}\text { ratio of } \\
\text { domestic } \\
\text { to inter- } \\
\text { national } \\
\text { price at OER }\end{array}$ & $\begin{array}{c}\text { ratio of } \\
\text { domestic } \\
\text { to inter- } \\
\text { national } \\
\text { price at } S E R\end{array}$ \\
\hline 1957 & 724 & 4.8 & 113 & 111 & 1.36 & 1.02 \\
\hline 1958 & 770 & 4.8 & 120 & 127 & 1.26 & 0.94 \\
\hline 1959 & 882 & 4.8 & 138 & 99 & 1.86 & 1.39 \\
\hline 1960 & 847 & 4.8 & 132 & 96 & 1.83 & 1.38 \\
\hline 1961 & 808 & 4.8 & 126 & 98 & 1.71 & 1.29 \\
\hline 1962 & 830 & 4.8 & 130 & 99 & 1.75 & 1.31 \\
\hline 1963 & 863 & 4.8 & 135 & 106 & 1.70 & 1.27 \\
\hline 1964 & 721 & 4.8 & 113 & 109 & 1.38 & 1.04 \\
\hline 1965 & 879 & 4.8 & 137 & 112 & 1.63 & 1.22 \\
\hline 1966 & 1092 & 4.8 & 171 & 132 & 1.73 & 1.30 \\
\hline 1967 & 1209 & 4.8 & 189 & 137 & 1.84 & 1.38 \\
\hline 1968 & 1124 & 4.8 & 176 & 158 & 1.48 & 1.11 \\
\hline 1969 & 1233 & 4.8 & 193 & 137 & 1.88 & 1.41 \\
\hline 1970 & 1160 & 4.8 & 181 & 110 & 2.20 & 1.65 \\
\hline 1971 & 1326 & 4.8 & 207 & 87 & 3.17 & 2.38 \\
\hline 1972 & 1829 & 7.5 & 183 & 103 & 2.37 & 1.78 \\
\hline 1973 & 2695 & 7.8 & 259 & 251 & 1.38 & 1.03 \\
\hline 1974 & 4970 & 8.0 & 466 & 481 & 1.29 & 0.97 \\
\hline 1975 & 6013 & 12.0 & 376 & 288 & 1.74 & 1.31 \\
\hline 1976 & 3465 & 15.0 & 173 & 228 & 1.01 & 0.76 \\
\hline 1977 & 4137 & 15.0 & 207 & 244 & 1.13 & 0.85 \\
\hline 1978 & 4361 & 15.0 & 218 & 344 & 0.85 & 0.63 \\
\hline $1979 p$ & 6005 & 15.0 & 300 & (288) & $(1.39)$ & $(1.04)$ \\
\hline
\end{tabular}

${ }^{1}$ medium quality, Dacca market.

${ }^{2} \mathrm{SER}=$ shadow exchange rate. Calculated with a scarcity conversion factor of 0.75 of the official exchange rate (OER).

${ }^{3}$ price of Thai 35 per cent brokens under government-to-government contracts with transport differential of 7 per cent to Chittagong, the main port. p provisional

the high level of food imports, the domestic price of rice in Bangladesh in most years was considerably higher than the international price, even after discounting for an overvalued exchange rate. For Bangladesh, the ratios reflect the low productivity in agriculture combined with growing demand due to population and income factors.

However, in the late 1970 s, the domestic/international price ratio at the shadow exchange rate dropped below 1.0. This shift in relative prices was caused in part by the government's deliberate policy of moderating consumer food prices aided by good harvests. But the currency devaluation in May 1975 is an additional factor so that for 1976 and 1977, the ratios at the official exchange rate are probably more representative of the price relative. For 1978, the world price changed abruptly, not the Bangladesh price.
Another relevant measure compares input/output price structures across countries. Peterson [1979] in estimating real prices received by farmers in 53 countries by deflating money prices of output with money prices of fertilizer found that during 1968-70 farmers in Pakistan received real prices because of fertiliser subsidies nearly as high as farmers in the major developed, exporting countries, where output prices were heavily supported by the respective governments.

Commerical imports in addition to food aid flows In the Asian context, the price of rice is perhaps the single most important barometer for measuring social well-being and political stability. In self-interest and in the interests of its citizens, governments are always attuned to the rice markets and often intervene quickly 
through stock release and/or importation if prices rise sharply relative to other prices.

During the 1970s, Bangladesh repeatedly used scarce foreign exchange to purchase grain on world markets - in addition to food aid imports - to ensure availability for ration distribution and to help moderate domestic prices. Some of the government's commercial purchases were made because of delays in food aid shipments; some because of differences in opinion (with donors) about import requirements; and some because of pending political events, as food 'insurance' prior to elections [Clay 1981]. But the fact that commercial purchases were made - particularly after 1975 when the Aid Consortium to Bangladesh informally guaranteed to underwrite all food grain import requirements - indicates a real perception that in the short-run consumer prices were likely to become intolerably high.

\section{Counterfactual: What if Output Prices Had Been Higher? \\ How responsive is output to prices?}

After 20 years and literally hundreds of empirical investigations, the notion that farmers respond to price changes - even farmers in predominantly subsistence economies - is no longer seriously at issue. The extent to which farmers respond, however, remains controversial, largely because of the difficulties of measuring supply response, particularly in a developing economy such as Bangladesh: during the past 20 years, agricultural technology has been changing rapidly, infrastructural development has been equally rapid, the pace of demographic change has been unprecedented. The extent and nature of government policy intervention have fluctuated with political instability. The dynamics of supply involve complex interrelationships at different levels of interaction.

Bearing in mind this caution about placing too much confidence in estimates of supply response, it should be noted that all the studies to date for Bangladesh report broadly similar conclusions. The aggregate response of rice production to price movements is positive, but low [Hussain 1964; Cummings 1974; Ahmed 1981]. This important finding is illustrated by the results of the analysis by the author of data for food grain production covering the period 1956/57 to $1979 / 80$, approximately the era of food aid and the introduction of modern agricultural inputs. ${ }^{2}$

${ }^{2}$ The supply functions estimated related area of production to prices of the previous years, and variables representing weather, variability of prices (risk) and a time trend. A complementary attempt to measure price effects on yield or total output were unsuccessful (for food grains and rice). In the estimated food grain output equations, for example, only trend and rainfall were significant, and together they explained over 80 per cent of the annual variation in output.
The estimated short-run price elasticity of supply of acreage is positive but low, at about 0.08: ie a 10 per cent increase in the relative price of food grains - for example, due to curtailed imports of food aid, or higher procurement prices - would induce farmers to increase their food grain acreage in the next period by only 0.8 per cent. On the base of $25 \mathrm{mn}$ acres, the implied increase would be about 200,000 acres which, at the mean yield level of 0.5 tons/acre, would translate into an output increase of only 100,000 tons. By comparison, less than 15,000 nutrient tons of fertiliser, a four per cent increase in current usage, would be required to raise output by the same amount.

In a land-scarce environment, questions arise about the source of expanded food grain area due to relative price changes. Until the late-1960s in Bangladesh, fallow land was available in the aus (early monsoon) season which could be brought into production without requiring modern technology or inputs, and without displacing other crops. But the current situation is basically that, apart from modern irrigation expansion, any short-run increase in food grain acreage must come out of other crops, primarily jute, pulses, and oilseeds. Declines in jute production have obvious implications for industrial production and for foreign exchange earnings, while declines in pulse and oilseed production adversely affect nutritional status.

\section{Long-run agricultural supply response and factor rigidity problems}

Bangladeshi farmers have pursued läbour-intensive, land-saving technologies in the face of declining real wages and rising land values, consistent with the Hayami and Ruttan [1971] 'induced innovation' theory, which emphasizes adjustment to factor proportions and changing relative prices over time. For example, attempts to introduce mechanised draft power as a labour substitute have failed for price and scale reasons. On the other hand, the evidence suggests that every available opportunity to intensify agricultural production on the limited land base has been taken.

The average annual 'net sown area' in Bangladesh during the late 1970 s was essentially the same as during the early $1950 \mathrm{~s}: 20.5$ to $21 \mathrm{mn}$ acres. Over the same period 'total cropped area' increased from 26.5 to $31.2 \mathrm{mn}$ acres. Thus, while the cultivable land base was at its limit throughout, the cropping intensity rose from 130 to 150 . The major sources of additional cropped acreage have been modern purchased inputs in the boro season (mechanised irrigation and HYV wheat seed) and, until the late 1960s, cultivation of former fallows in the aus season. Labour-intensive farmer innovations have also increased cropped 
acreage; for example, dibble-sowing of rice on saline soils and cultivation of wheat on impervious soils through ridging and frequent hand irrigations. Both practices have spread rapidly during the past several years. Another land-augmenting technology which has been used increasingly during the 1970 s - crop irrigation with the hand pump - combines labour intensity with a purchased input [Brammer 1980].

As innovative as the farmers or the research establishment are, the major source of growth in the medium term - through increased cropping intensity and yields - is likely to continue to be additional modern purchased inputs. So far prices have not constrained farmers' use of new inputs. The problem has been the inadequate supply to the farmer dictated by finance and investment at the macro level.

\section{Distribution of benefits to producers from higher food grain prices}

A substantial proportion (in some years, the majority) of farm households are net purchasers of rice [Rahman 1980; Ahmed 1981]. Higher rice prices effectively decrease the incomes of these households. Moreover, the seasonal nature of sales at lower, postharvest prices and repurchases later at higher prices exacerbates the loss of income. This evidence of the marketing structure in Bangladesh obliges us to qualify the commonly held but simplistic notion that farmers generally benefit from higher output prices, including price supports. Price support measures may be beneficial or detrimental, depending on how they are targeted. Thus a reduction in the large seasonal fluctuation in prices rather than an increase in average prices without stabilisation would probably be of greater benefit to the majority of Bangladeshi farmers. Moreover, as Ahmed [1981:40] argues, if price support programmes require large budgetary resources and therefore compete with infrastructural investment programmes (eg irrigation development), 'questions of priority become urgent'.

\section{Food Aid and Agricultural Policy Complacency}

\section{Changing sectoral priorities}

The role of food aid in the evolution of development policy is a complex issue of political economy. In 1959 there was a clear shift of emphasis in policy for East Pakistan towards encouraging agricultural development. This followed years of neglect and stagnation in the agricultural sector. It also followed the advent of the food aid programme which provided direct support for meeting short-run welfare demands, due to growing food deficits, without necessitating cuts in long-run development investment. The productivity gains of the 1960s and 1970s reflect the increased priority attached to agriculture (Figure 2).

At the same time, efforts to utilise fully the available domestic and aid resources, or to mobilise additional resources, for development investment in Bangladesh have been less than satisfactory. The public-sector revenue foregone (opportunity loss) because of subsidies to consumption and production amounting to a substantial portion of total potential revenue, became particularly apparent in the 1970s. Food aid and other commodity assistance facilitated these subsidy policies. However, it is not certain that the subsidy policies, once established, would have been different if food aid transfers had been smaller.

\section{Agricultural investment and development policies}

The sectoral allocations in development budgets provide an indication of the government's investment priorities. This increased priority accorded to agriculture from the beginning of the 1960 s is reflected dramatically in the doubling of agriculture's share of planned development expenditure. The share going to water and power - of which irrigation and flood control comprised about one-half - doubled between the early 1950s and the Third Plan (1965-70); and the new rural works programme claimed a growing percentage of investment resources.

Concurrent with increased agricultural investment, which focused on the supply and subsidisation of modern agricultural inputs, the government enacted several policy changes favourable to the farm sector. Export duties on jute and other export commodities were reduced. Marketing, price, and procurement controls on food grains were eased. In addition, an internal food grain buffer stock system was initiated to help stabilise prices. Studies by Falcon and Gotsch [1966] and Mason [1966] stressed the importance of the food aid programme in providing the cushion against which the liberalisation of agricultural and trade policy took place. ${ }^{3}$

The sectoral allocations of development expenditure in Bangladesh's First Five Year Plan (1973-78) were broadly similar to those in Pakistan's Second Plan.

${ }^{3}$ Mason [1966] summarised this by arguing, '. . . if no (PL 480) surpluses had been available, the result would probably have been, in the Pakistan of the 1950s, a chaotic food price situation in which attempts at rigid controls would have been accompanied by black markets, large price fluctuations, and great price differentials between markets. This, in fact, aptly describes the conditions in grain markets during the short period following the advent of the Ayub regime (in 1958) when controls were sharply tightened. PL 480 shipments may have had an adverse impact on agricultural output in the 1950 s, but their availability in the 1960s made possible a number of measures which taken together with other actions bearing on farm incentives set the stage for a very substantial increase in agricultural productivity' (pp 52-53). 
Annual public-sector development expenditure in the agricultural sector as a percentage of total development expenditure

\begin{tabular}{|c|c|c|c|c|c|c|c|}
\hline & \multicolumn{6}{|c|}{ revised budget } & \multirow{2}{*}{$\begin{array}{c}\text { budget } \\
1979 / 80\end{array}$} \\
\hline & $1973 / 74$ & $1974 / 75$ & $1975 / 76$ & $1976 / 77$ & $1977 / 78$ & $1978 / 79$ & \\
\hline $\begin{array}{l}\text { Agriculture } \\
\text { Rural development } \\
\text { Water and flood control }\end{array}$ & $\begin{array}{r}12.4 \\
6.6 \\
15.0\end{array}$ & $\begin{array}{r}12.2 \\
5.4 \\
16.4\end{array}$ & $\begin{array}{r}12.1 \\
5.1 \\
14.3\end{array}$ & $\begin{array}{r}15.2 \\
4.2 \\
11.9\end{array}$ & $\begin{array}{r}12.8 \\
4.2 \\
11.9\end{array}$ & $\begin{array}{r}14.6 \\
3.9 \\
10.8\end{array}$ & $\begin{array}{r}12.7 \\
4.1 \\
10.3\end{array}$ \\
\hline $\begin{array}{l}\text { Total agricultural } \\
\text { sector }\end{array}$ & 34.0 & 34.0 & 31.5 & 31.3 & 28.9 & 29.3 & 27.1 \\
\hline $\begin{array}{l}\text { Total development } \\
\text { expenditure }\end{array}$ & 100.0 & 100.0 & 100.0 & 100.0 & 100.0 & 100.0 & 100.0 \\
\hline
\end{tabular}

Source: Bangladesh Ministry of Finance; World Bank.

The budget share allocated to the agricultural sector (including water resources and rural development) was 26.3 per cent. However, because the performance of public-sector expenditure in agriculture was significantly better than in most other sectors, the estimated actual share going to agriculture during the plan period was 32 per cent (see Table 2 ). The better performance of agriculture reflects in part the higher priority attached to the sector in annual development budgets as distinct from the Five Year Plan. On the other hand, there was a downward trend in the share of annual development expenditure allocated to the agricultural sector during the 1970 s.

Separating out the components of this trend indicates the danger of making inferences from movements in budgetary aggregates. The relative decline in agriculture's share came primarily in the water and flood control subsector. This reflects the policy shift in the late 1970s to transferring small-scale irrigation into the private sector and the reduction in irrigation subsidies. Institutional rigidities, especially in the large-scale irrigation subsector, also led to indecision about future investment strategies. There was a slight upward trend in the agricultural subsector share which includes crop research, extension and input supply.

Development budget figures can also be misleading in that they often include current expenditure components which cannot be considered as development investments. In agriculture, for example, substantial subsidies on fertiliser have been subsumed in the annual development budget. While the subsidies represent real resource transfers to the farm sector, their inclusion in the development budget overstates the absolute value of capital and intermediate investment resources going to agriculture. In relative terms, it is difficult to assess how these hidden components have affected agriculture's budget share, because other sector estimates reflect the same accounting procedures. The data do not permit a full analysis.

The original rationale for input subsidies was to encourage the adoption of modern technologies. Whether or not subsidies can still be justified is an important issue. The discussion above suggests that farmers' incentives to use modern inputs are high without subsidies. Regardless, these subsidies have involved large resource transfers to the agricultural sector, particularly as the volume of modern inputs has increased. In the late 1970s, the fertiliser subsidy was equivalent to more than 10 per cent of the sector's estimated earnings from rice sales. In addition there have been large, variable and difficult to estimate irrigation subsidies.

While the agricultural sector as a whole has benefited from subsidy transfers, the distribution of benefits has been weighted toward those farmers having access to input supplies at or near the official government prices. Subsidies and scarcities generally exacerbate inequalities. Regarding the efficiency of use of 
subsidised inputs, divisibles like fertiliser that can easily be retraded have been utilised fully under current agronomic practices (abstracting from smuggling losses). But indivisibles like irrigation equipment have been grossly underutilised, in part because of the subsidies [Islam 1977].

In addition to supporting agriculture through increased development expenditure, other government policies and programmes have benefited the rural sector - directly and indirectly - during the food aid era. Several policy reforms that were made in the early 1960s were mentioned above. Others, that were made in the 1970s after liberation, pertain to procurement, taxation and exchange-rate policies.

Food grain operations; the government has operated an internal rice procurement programme in Bangladesh almost continuously since the wartime period of the 1940s. The initial motivation for procurement was to secure through compulsory levy all surplus grain that was available in the countryside for public-sector ration distribution in non-producer, mainly urban, areas. It was fundamentally a supply operation, not a price support mechanism for farmers [Knight 1954].
The system remained essentially unchanged through the 1950 s and 1960 s, with compulsory procurement maintained primarily in the border areas to discourage smuggling. In most areas procurement was generally voluntary. In absolute terms, or as a percentage of public-sector food distribution, the procurement programme up to the mid-1970s was not large. The procurement price did, however, function in varying degrees as a floor price to farmers. Once more in 1973-76 the government reverted in a food crisis situation to compulsion to sustain supplies to the public distribution system, giving prominence to procurement sustained by the subsequent change of policy.

In 1975/76, the government began to use procurement explicitly as an instrument of producer price support: the procurement price of rice was raised substantially relative to market prices, and it was announced during the aman planting period (previously, prices had been announced at harvest time). Thus, procurement prices began to function more as incentive support prices for farmers than as floor prices, and the response was dramatic. Curiously, food aid played a key role in the procurement policy shift, although in a rather perverse

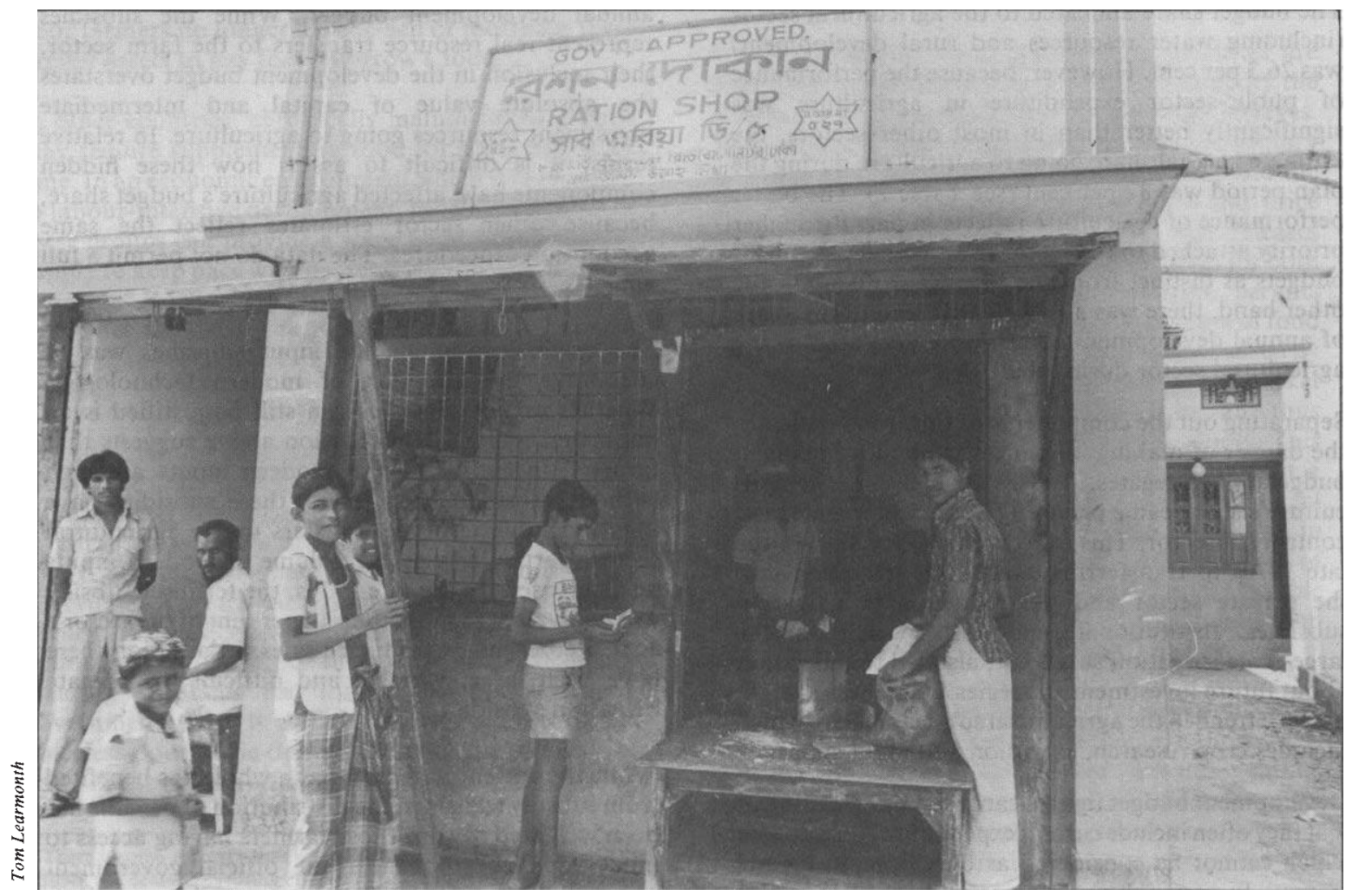

Government ration shop in Dacca. 
way. Food aid donors had informally agreed to underwrite total import requirements for Bangladesh; but cereals food aid is virtually all wheat, which does not satisfy the ration system requirements for rice, the preferred grain. To satisfy its ration system constituents (public servants, military, students, etc), the government had to turn to domestic procurement as the source of rice. The primary motivation for procurement, as in the early years, was still to supply the ration system. Whatever the motivation, the effects for farmers of a more positive procurement policy dependent on voluntary sales were higher effective floor prices and some degree of price stabilisation. Again, as with subsidies on inputs, the intersectoral resource transfers inherent in procurement purchases primarily benefited surplus farmers with access to the procurement system.

Agriculture's declining tax burden: the history of agricultural (primarily land) taxation in Bengal is long and controversial. What is striking about the recent past is the virtual absence of all direct taxes on the agricultural sector, the sector which accounts for more than half of GDP. During the early 1950s, after abolition of Zamindari intermediaries, land revenues accounted for roughly 15 per cent of total direct tax receipts. The percentage rose to 30 per cent by the early 1960s, but dropped back to 15 per cent for the remainder of the decade. In addition to land taxes, the government taxed upper-level agricultural incomes, mainly the tea estates, which yielded two per cent of total tax revenues during the 1960 s.

In 1972 after liberation, the new Bangladesh Government effectively eliminated agricultural land taxes by exempting virtually all except tea estates. Further, the government suspended agricultural income taxes in 1974, and abolished them altogether two years later. While some incidental local taxes remained in the post-liberation period, the direct tax burden of the agricultural sector during the past decade has been virtually nil.

The net indirect tax burden on agriculture is difficult to determine. The standard argument that low food prices due to food aid imports have taxed farmers excessively does not seem to hold in view of the price analysis above. That food imports prevented higher profits or resource transfers to agriculture by dampening scarcity prices is certain. However, Bangladesh has almost continually had an overvalued exchange rate which implicitly taxed exports but kept import prices low, with both positive and negative implications for agriculture. Modern inputs to production - mostly imported - have been cheaper, benefiting food grain production, an importsubstitution activity which has utilised most of the imported inputs. But jute production, which is largely exported, has been taxed indirectly by overvaluation (the benefits from cheaper input prices notwithstanding). Given the relative importance of sectoral earnings from rice versus jute, the net benefit to the farm sector from overvaluation has probably been positive, although for individual farmers the reverse may have been the case.

\section{Resource constraints and aid dependency}

Bangladesh has had a persistent balance of payments problem. Most capital and many intermediate goods, including energy, have necessarily been imported, while export earnings to finance imports have been derived predominantly from a single agricultural commodity: jute. The growing food deficits and consequent food imports have cut into the forign exchange resources available for development imports. Moreover, as jute and rice compete for land, periodic food crop short-falls have inevitably led to short-run declines in jute acreage and production which in turn reduced foreign exchange earnings, adding to current account deficits and long-term debt.

Two terms-of-trade crises - one following the Korean war and the other in the early 1970 s - underscored the vulnerability of Bangladesh's trade structure to external economic pressure. In 1952 at the end of the Korean war commodity price boom, Pakistan's overall terms-of-trade index fell 39 per cent over two years; East Pakistan's jute export prices fell 50 per cent in one quarter. The government's initial response to this crisis was to impose strict controls on trade through export taxes, tariffs, and quantitative restrictions on imports. These policies, which 'represented an almost classic case of turning the (domestic) terms of trade against agriculture and protecting domestic manufacturing' [Lewis 1968:63], eventually gave way to more open trade policies, with reductions in export taxes on agricultural goods. Growing foreign aid also helped to finance import requirements. By the late 1960 s, the terms of trade had recovered to Korean war levels (in part due to the Vietnam war commodity price boom), and the volume of exports reached new highs.

The second terms-of-trade crisis occurred in the early 1970 s during the period of rapid inflation in world food and energy prices. The overall terms of trade fell 32 per cent in one year, and reached a low point two years later at 56 per cent of the pre-crisis level. This crisis hit just after liberation when the economy was still in disarray, and it was compounded by a series of poor harvests caused by drought and flooding which simultaneously increased the need for food imports and reduced the quantities of jute available for export. The severity of the balance of payments problem facing Bangladesh in the 1970s is reflected in the ratio 
of annual export earnings to import expenditures which for most of the decade was less than 40 per cent. In contrast, during the entire decade of the 1960s, East Pakistan exports covered 84 per cent of total visible imports, including inter-wing trade with West Pakistan.

In the short-term, Bangladesh had little recourse but to depend on foreign aid to meet minimum food consumption requirements and to maintain development projects and investments. By the late 1970 s, total foreign aid flows to Bangladesh as accounted in the budget were equivalent to more than 10 per cent of GDP and 75 per cent of development expenditures [World Bank 1980]. Food aid in the latter period contributed roughly one-quarter of total foreign aid.

Food aid helped to mitigate the balance of payments crisis of the mid-1970s. But Bangladesh was still obliged to purchase substantial quantities of food commercially [Islam 1977:111]. In fact, in its attempt to ensure a minimum supply of food grains, the country spent itself into 'bankruptcy' in 1974, which meant that it had to agree to a consortium of aid donors under the auspices of the World Bank. In spite of the high level of food imports - which, relative to total export revenues, were two and one-half times higher than in any other major food-deficit country during the late 1960s and early 1970s [Siamwalla and Valdes 1980] - significant adjustments in food consumption were also taking place internally people went hungry and starved. Table 3 shows the relationship between aid resource transfers and export earnings during the 1970 s. In FY 75 , total current export earnings would not even have paid for food-aid imports, let alone the 687,000 tons of commercial food imports and all other imports items.

Public sector domestic resource mobilisation for current and investment expenditures has also been closely linked to foreign trade and aid. On the one hand, taxes on imports have consistently provided about one-third of total government revenue in the 1970s, even though a few 'items of essential need' such as food grains, edible oils, fertiliser, and seed have been exempt from import duties. On the other hand, but not accounted for in the revenue budget, concessional commodity aid that is sold domestically on government account has generated substantial extra-budgetary finance, so-called counterpart funds. For example, in 1978-79, food grain imports to Bangladesh totalling 1,165,000 tons were financed on concessional terms, the financial cost to Bangladesh being only 10 per cent of cif value. Subsequent ration system sales resulted in a net financial contribution from food aid equivalent to 11 per cent of total revenue, or nine per cent of the total development expenditure, in $1978 / 79$. The implicit budgetary dependence on food aid was even higher in most other years during the 1970s.

Budgetary dependence on food aid involves an inherent conflict between aid and agricultural development, which is manifest in the opposite perspectives of a recipent country's finance and agriculture ministries. The Ministry of Agriculture, which is in charge of

Table 3

Aid disbursements compared with export earnings in Bangladesh

(million US dollars - current)

\begin{tabular}{ccccccc}
\hline $\begin{array}{c}\text { fiscal } \\
\text { year }\end{array}$ & $\begin{array}{c}\text { total } \\
\text { aid }\end{array}$ & $\begin{array}{c}\text { of which, } \\
\text { food } \\
\text { aid }\end{array}$ & $\begin{array}{c}\text { food aid } \\
\text { as \% of } \\
\text { total aid }\end{array}$ & $\begin{array}{c}\text { merchandise } \\
\text { export } \\
\text { earnings }\end{array}$ & $\begin{array}{c}\text { ratio of } \\
\text { total aid } \\
\text { export earnings }\end{array}$ & $\begin{array}{c}\text { ratio of } \\
\text { food aid/ } \\
\text { export earnings }\end{array}$ \\
\hline $1971 / 72$ & 227 & 103 & 45 & na & - & - \\
$1972 / 73$ & 421 & 121 & 29 & 340 & 1.24 & 0.36 \\
$1973 / 74$ & 640 & 300 & 47 & 362 & 1.77 & 0.83 \\
$1974 / 75$ & 924 & 380 & 41 & 358 & 2.58 & 1.06 \\
$1975 / 76$ & 814 & 307 & 38 & 380 & 2.14 & 0.81 \\
$1976 / 77$ & 502 & 106 & 21 & 460 & 1.09 & 0.23 \\
$1977 / 78$ & 797 & 190 & 24 & 497 & 1.60 & 0.38 \\
$1978 / 79$ & 1016 & 187 & 18 & 603 & 1.68 & 0.31 \\
$1979 / 80^{2}$ & 1366 & 394 & 29 & 743 & 1.84 & 0.53 \\
\hline
\end{tabular}

Notes: ${ }^{1} 70-75$ per cent of export earnings come from jute and jute commodities

${ }^{2}$ provisional figures.

Source: Planning Commission; IBRD [1980]. 
production programmes, is organised to promote increased farm productivity and output. The Ministry of Finance, on the other hand, loses an important source of revenue as domestic production increases and aid financed imports decrease. As food aid has historically been broadly additional to other aid, the revenue losses from a reduction in food aid are generally not compensated for by other forms of aid.

The inter-ministerial budget debates in Bangladesh, as well as the aid consortium negotiations, have continually grappled with this conflict. Even the data reflect the different incentive structures: the Ministry of Agriculture's estimates of food production (or prices) have been uniformly higher (lower) than corresponding estimates made by the food or finance ministries. In the final analysis, the actual budget allocations to various sectors have reflected the compromises. reached in the planning process. What would have been agriculture's investment share, or the level of food and agricultural subsidies, in the absence of food aid resource transfers, is a subject only for speculation.

In principle, counterpart funds from food aid sales are supposed to be used only for development projects. In practice, their use is virtually impossible to document. Even where they are explicitly linked to additional activities, assessment is ultimately a matter of judgement. During the 1970s in Bangladesh, the consumption subsidies transferred through the ration system were greater than the revenues generated by the sale of food aid commodities. In the absence of these counterpart funds, the high level of consumption subsidies simply could not have been maintained without a significant reduction in development expenditure. Recent history has also shown that during periods of financial crisis, successive governments have steadily maintained the food subsidies, which, in effect, has made development investment and implementation a residual category. The consumption imperative as perceived by the government has thus determined, in part, the level and pace of development.

Even if the food subsidies were significantly reduced or phased out entirely, the larger issue for Bangladesh is the need to mobilise additional resources from within. During the 1950s, the gross domestic savings rate in Pakistan averaged roughly six per cent of GNP. By the late 1960s, the rate for East Pakistan had risen to 10 per cent [Alamgir and Rahman 1974], but in the context of political and economic policies that ultimately brought about the painful birth of an independent Bangladesh.

The crises of the post-liberation period, however, brought about a collapse of the economy to the extent that 101 per cent of the GDP in 1977 went for current consumption, at lower per capita levels than during the 1960s. Aggregate domestic savings were negative. Foreign aid was equivalent to total investment plus one per cent of current consumption.

Yet, as evidenced by the high rates of return to private investment in the new agricultural technologies, surpluses are being generated by a sub-group in the farm sector that, in the aggregate, are not being captured for investment. Direct agricultural land and income taxes are effectively non-existent, excise taxes and export duties on agricultural commodities are minimal, and indirect taxation of the farm sector through price and exchange rate policies is probably, on balance, negative. The question for Bangladesh is not whether these surpluses should be taxed for investment purposes, but when and how. The difficulties of designing appropriate tax mechanisms, which should not be understated, involve both distributional and cost-effectiveness issues.

\section{Possible Incentive Effects}

\section{Public works programme}

The Rural Works Programme of the 1960s was designed specifically to provide a new framework of organisation to rehabilitate, maintain, and develop rural physical infrastructure - canals, embankments, and roads - which would contribute directly to farmers' incentives for increasing agricultural production and marketing. The organisational framework of planning and implementation was decentralised. Finance, however, was provided directly from counterpart funds from food aid. Thomas [1968] estimated that the net annual increase in the value of production due to the cumulative progress of the works programme was equivalent to 2.5 per cent of total rice production with an implied benefit/cost ratio of 4.0 for East Pakistan. Thomas also considered that the programme was largely additional to other development expenditure: that

had it been necessary to obtain the necessary resources from the rural people or to add the cost of the programme to the already overcommitted development budget, it is highly questionable whether a programme large enough to be of significance could have been launched. The increased rural incomes generated new demand for food commodities, thus making a larger PL 480 programme possible, while the works programme, without substantial foreign exchange costs, provided a productive use for PL 480 aid that was non-inflationary and promoted agricultural growth.

[Thomas 1968:290] 
Ultimately this decentralised programme, linked to the increasingly corrupted and discredited system of basic democracy [Sobhan 1968] collapsed in the period of political instability leading up to the liberation war. The major economic criticism levelled at the programmes is not that rural works have failed to enhance productive capacity but that the distribution of likely benefits would be highly skewed to landlords and richer surplus producers.

For a variety of reasons, including the general breakdown in administration, the public works programme in Bangladesh initially lacked momentum during the post-liberation period. The character of the programme was changed dramatically before it began to expand rapidly in the mid-1970s. First, it had been transferred from the Ministry of Rural Development to the Ministry of Relief and Rehabilitation. Second, the design of works projects was now centralised in the new ministry, but the projects were actually controlled by various outside (foreign) agencies and implemented through local contractors rather than through local government committees. Third, and related to this, there were problems of coordination between different projects within the same regions. Fourth, wages were now paid in kind, not out of counterpart funds; hence the new name: the Food for Work Programme. This programme, the largest supported by food aid, has been the subject of intense controversy. The in-depth evaluation by the Bangladesh Institute of Development Studies and IFPRI will, it is hoped, produce a broad and balanced assessment of the impact of food for work.

\section{Food aid and market development}

One criticism of food aid has rested on the 'inappropriate commodity' argument: supplying wheat to a rice culture, it is argued, not only represents a form of cultural imperialism, but the practice over time might also develop a country's taste, and therefore a demand, for a product which in some environments can only be imported.

In Bangladesh the argument cannot be sustained in this simple form. First, while it is true that wheat has been, and still is, considered an inferior commodity compared to rice, its supply has represented a cheaper source of calories than rice, whether through concessional or commercial purchase importation. The different demand elasticities for wheat and rice across income groups reflecting actual consumption suggests an opportunity for targeting the benefits from food aid wheat to the poor. The extent to which this has been achieved requires careful analysis of the operation of the public distribution system [Ahmed 1979]. ${ }^{4}$

${ }_{4}^{4}$ See for example Jackson [1982] for a summary of critical evidence and further references.
Second, many regions (soil types) in Bangladesh are well-suited for the production of wheat during the dry season, with or without irrigation. The development of a taste for wheat through exposure to food aid over the past 25 years has spurred a domestic market and thereby facilitated a rapid expansion of wheat production. From about 23,000 tons annually during the 1950 s, wheat production rose to some 200,000 tons by the late $1960 \mathrm{~s}$, and to around $12 \mathrm{mn}$ tons in $1980 / 81$. The wheat boom of the late 1970s more than compensated for the slower growth in rice production during the same period. It had a significant positive effect on output of calories and protein and rural employment, even allowing for substitution of wheat for pulses and oilseeds.

\section{Conclusions}

Bangladesh is frequently cited as an example of the adverse affects of food aid on domestic agriculture. Yet the evidence does not sustain this view. The direct price effects of food-aid imports to Bangladesh during the past 25 years do not appear to have caused disincentives to farmers; rather, domestic rice prices for most of the period were higher than world prices. Nor did the domestic terms of trade move against farmers, nor the profitability of food grain production decline $v i s-\grave{a}$-vis other crop alternatives. The highyielding varieties that were introduced during the 1960s greatly enhanced profitability.

The major constraint on the growth of food grain productivity and production was the inadequate supply of modern agricultural inputs, which was primarily due to an overall capital resource constraint in Bangladesh. A wider analysis of the rural economy also suggests that there are other structural constraints on facilitating agricultural development through the price mechanism. Only a small minority of producers are well placed to benefit from output price incentives and have favoured access to subsidised inputs.

Food aid resource transfers made a major contribution toward alleviating the foreign exchange constraint, thus allowing for higher investment in intermediate goods imports than would have been the case without food aid. Regarding development policy, the evidence suggests that the food aid resource transfers were used more efficiently, or productively, during the 1960 s than during the 1970 s, but in a context that probably was not sustained. The 1970s have been more turbulent in terms of both the domestic political, and the world economic, environment. The tensions in macro economic and agricultural sector policies are more severe. It is, however, difficult to envisage a sustainable counterfactual scenario in which significantly lower levels of food aid would have resulted in more rapid and equitable agricultural development. For references see page 61 . 